\title{
Mouse as a Model of Growth Retardation in Cystic Fibrosis
}

\author{
LEWIS A. ROSENBERG, MARK D. SCHLUCHTER, ALBERT F. PARLOW, AND MITCHELL L. DRUMM \\ Departments of Genetics [L.A.R., M.L.D.], and Pediatrics [M.D.S., M.L.D.], Case Western Reserve University, Cleveland, OH 44106; \\ National Hormone and Peptide Program [A.F.P.], Harbor-UCLA Medical Center, Torrance, CA 90509
}

\begin{abstract}
Cystic fibrosis (CF) is an autosomal recessive disease that results in lung failure and premature death. A long recognized symptom of CF is growth failure, which is clinically relevant because it correlates with the severity of lung disease. We describe growth retardation in a mouse model of $\mathrm{CF}$ and discuss its potential for modeling certain aspects of human growth retardation. Mice with a null mutation in Cftr (cystic fibrosis transmembrance conductance regulator) were compared with wild-type (WT) mice at 31, 45, and $84 \mathrm{~d}$ of age. CF mice were severely growth retarded in weight and length compared with wild-type controls. Serum insulin like growth factor I (Igf-1) was lower in CF mice by $31-55 \%$ (depending on age and sex) and it significantly correlated with the size of mice after controlling for gender, age, and Cftr genotype. There was a marginally significant deficiency of serum growth hormone (Gh) in CF females, but not males. Our findings were consistent with models of an energy deficit in rodents. We, therefore, assessed food intake and found no difference between $\mathrm{CF}$ and WT mice, suggesting that $\mathrm{CF}$ mice had a malabsorption-mediated energy deficit. We argue that $\mathrm{CF}$ mice are suited to study the effects of intestinal disease on growth as well as other proposed growth-modulating processes. (Pediatr Res 59: 191-195, 2006)
\end{abstract}

$\mathrm{C}$ ystic fibrosis $(\mathrm{CF})$ is a fatal autosomal recessive disease. The absence or reduction of functional CFTR (cystic fibrosis transmembrane conductance regulator) affects multiple organs; the impact on the lungs is the cause of most morbidity and mortality in humans, and the majority of $\mathrm{CF}$ patients eventually succumb to lung failure. CF patients are also growth retarded (1-3), which is clinically relevant not only because it affects the quality of life for patients, but also because the severity of growth retardation correlates with the severity of lung disease $(2,3)$. Furthermore, studies in which CF patients have benefited from chronically administered growth hormone suggest that generation of a growthpromoting physiologic state may improve lung function and clinical status $(4,5)$.

Malnutrition is a major cause of growth retardation in $\mathrm{CF}$ patients and results from loss of exocrine pancreatic function, elevated energy requirements (likely due to increased work of breathing), anorexia during pulmonary exacerbations, and other factors (6). Other proposed contributors to the growth deficit include a down-regulation of growth by inflammatory

Received June 17, 2005; accepted August 12, 2005.

Correspondence: Mitchell L. Drumm, Ph.D., Case Western Reserve University, 2109 Adelbert Rd. BRB 830, Cleveland, OH 44106; email: mitchell.drumm@case.edu

This work was supported by NIH grant HL68883 from the National Heart Lung and Blood Institute and Core Center grant DK27651 from NIDDK.

DOI: 10.1203/01.pdr.0000196720.25938.be cytokines (7), a primary cellular energy wasting defect $(8,9)$, and a direct effect on growth or metabolism from loss of hypothalamic CFTR $(10,11)$. Modern therapies including aggressive nutritional intervention have led to improved growth in CF patients; nonetheless, studies show that average height and weight are still significantly below normal $(12,13)$. The goal of achieving normal growth for all CF patients would benefit from better implementation of existing therapies as well as development of novel treatments. Further study of the mechanisms of $\mathrm{CF}$ growth failure may benefit from utilization of an animal model.

We propose that study of CF mice, which also have reduced growth $(14,15)$, will yield insight into the mechanisms of growth retardation. CF mice containing a null mutation in $\mathrm{Cftr}$ have severe intestinal disease, evidence of pancreatic changes that are mild compared with humans, and normal lung function $(16,17)$. CF mouse growth including length measurements and major regulatory hormones has not been described in detail. To establish a mouse model of CF growth retardation, this paper describes growth and aspects of growth regulation in mice with a null mutation in Cftr.

\section{METHODS}

Mice. CF mice used in this study were homozygous for a null mutation in $C f t r\left(C f t r^{\text {tmIUnc/tmIUnc }}\right)$ that produces no functional protein $(15,18)$ and were bred to congenicity on $\mathrm{C} 57 \mathrm{BL} / 6 \mathrm{~J}$ for at least 12 generations. Homozygous wildtype littermates $\left(\mathrm{Cftr}^{+/+}\right)$served as controls. All mice were offspring of $C f t r$ heterozygotes $\left(C f t r^{t m I U n c /+}\right)$. Hormones and mRNA were assayed at 31 , 45 , and $84 \mathrm{~d}$ to achieve a temporal profile extending from juvenile to adult ages. Mice were housed at constant temperature $\left(22^{\circ} \mathrm{C}\right)$ on a $12 \mathrm{~h} \mathrm{light/dark}$ cycle alternating at $0600 \mathrm{~h}$ and $1800 \mathrm{~h}$. To aid survival of $\mathrm{CF}$ mice, all mice were weaned at $28 \mathrm{~d}$ of age, fed an enriched diet (9F Sterilizable Rodent Diet 7960, Harlan Teklad, Madison, WI) and CF mice were provided a Colyte solution (peg-3350 \& electrolytes for oral solution - Schwarz Pharma, Milwaukee, WI) in place of water (19). Known deaths accounted for $40 \%$ of CF mice assigned to this study. Mice were anesthetized with avertin $(0.5 \mathrm{mg}$ tribromoethanol/g body weight ip) and euthanized by exsanguination via heart puncture between $1000 \mathrm{~h}$ and $1200 \mathrm{~h}$. Whole pituitaries and small portions (20 $\mathrm{mg}$ ) of the left lateral lobe of the liver were dissected, frozen in liquid nitrogen, and stored at $-80^{\circ} \mathrm{C}$ for use in quantitative PCR. Blood was stored on ice during dissection and centrifuged at $3500 \mathrm{~g}$ to separate serum which was stored at $-80^{\circ} \mathrm{C}$ until use in hormone measurements. This study was approved by the Institutional Animal Care and Use Committee.

Growth analysis. All mice were weighed weekly. Only mice surviving until $84 \mathrm{~d}$ were included in growth curve analysis, to avoid artefactual shifts from deaths of mice. Mice were measured from the tip of the nose to the base

Abbreviations: CF, cystic fibrosis; Cftr, cystic fibrosis transmembrane conductance regulator 
of the tail when they were anesthetized before euthanization to avoid innacuracy from movement of mice.

Food consumption study. WT and CF mice were separately caged beginning at day 35 and continuously provided with 50 to $100 \mathrm{~g}$ of food. Weights of food and mice were recorded daily between $900 \mathrm{~h}$ and $1100 \mathrm{~h}$. Food intake was measured from day 37 through day 46 (provided food was initially measured on day 36) and only mice that survived through day 46 were included in analysis.

RNA extraction and $\boldsymbol{c D N A}$ synthesis. RNA was extracted from pituitaries and livers using $1 \mathrm{~mL}$ Trizol (Invitrogen, Carlsbad, CA) according to the manufacturer's instructions and reconstituted in The RNA Storage Solution (Ambion). RNA was quantified spectrophotometrically. cDNA was synthesized in duplicate for each RNA sample with $1 \mu \mathrm{g}$ liver RNA or $0.25 \mu \mathrm{g}$ pituitary RNA using M-MLV-RT (Invitrogen, Carlsbad, CA) according to the manufacturer's instructions. RT-PCR samples excluding M-MLV-RT served as negative controls in quantitative PCR.

Quantitative PCR. Oligonucleotide primers for quantitative PCR were based on mRNA sequences obtained from NCBI; Accession numbers were as follows: $18 S$ subunit ribosomal RNA (18S): $\times 00686$, Gh: $\times 02891$, Igf-1: NM_184052. Primers designed using MacVector 7.2 (Accelrys, San Diego, CA) and product sizes were as follows: $18 S$, 5'-ATTGACGGAAGGGCAC-

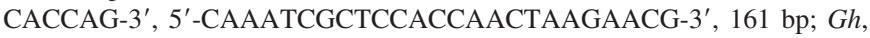
5' -TGAGAAACTGAAGGACCTGGAAGAG-3', 5'-GTTGGCGTCAAACTTGTCATAGG-3', 115bp; Igf-1, 5'-CGCTCTGCTTGCTCACCTTCAC-3', 5'-CACTCATCCACAATGCCTGTCTG-3', 178 bp.

Real-time quantitative PCR was performed on a Rotor-Gene 3000 (Corbett Research, Sydney, Australia) using Sybr Green I (Sigma Chemical Co.) as a fluorescent indicator. Sybr Green I, provided as a $10,000 \times$ concentrate, was diluted to a $10 \times$ solution in TAE. This solution was found to be stable at $4{ }^{\circ} \mathrm{C}$ for at least one month. PCR was performed with Platinum Taq (Invitrogen) according to the manufacturer's instructions except for the addition of $0.2 \mu \mathrm{L}$ of $10 \times$ Sybr Green I to each $20 \mu \mathrm{L}$ reaction. Five percent of synthesized cDNA was used in each PCR reaction, except for $18 S$ amplification for which $0.05 \%$ was used.

Relative values were calculated such that all samples were compared with the WT $31 \mathrm{~d}$ mean, which was set to 1 . The relative value of each sample was based on a threshold fluorescence set in the exponential phase of amplification. The following equation determined the relative value of each sample: $\mathrm{E}^{\left(\mathrm{Ct}_{\mathrm{wt}}-\mathrm{Ct}_{\mathrm{s}}\right)}$, where $\mathrm{E}$ is the efficiency of the reaction, $\mathrm{Ct}_{\mathrm{wt}}$ is the average threshold-crossing cycle number for the $31 \mathrm{~d} \mathrm{WT}$ samples, and $\mathrm{Ct}_{\mathrm{s}}$ is the threshold-crossing cycle number of the sample. The efficiency was determined empirically for each gene by amplifying 4 serial 4 -fold dilutions of cDNA with each primer set. The slope of the line created by plotting $\log _{10}$ (concentration) by $\mathrm{Ct}$ was used to find the efficiency with the equation: $\mathrm{E}=10^{(-1 / \text { slope })}(20)$. The efficiencies found for each gene were as follows:18S: 2.00; Gh: 1.97, Igf-1: 1.98. The relative values for $G h$ and Igf-1 were normalized to the relative value of the housekeeping gene $18 \mathrm{~S}$, to correct for variation in RNA concentration or cDNA synthesis efficiency.

To ensure the quality of reported data, each RNA sample was used to make cDNA in duplicate. Each duplicate was quantified separately and then averaged to yield a final result. If duplicates differed by more than a factor of two, the result was discarded. All analyses compare samples within the same PCR reaction, to avoid interassay variation.

Hormone measurements. Serum Gh was measured by RIA (National Hormone \& Peptide Program, Harbor-UCLA Medical Center, Torrance, CA). Serum Igf-1 was measured using Rat Igf-1 EIA (Diagnostic Systems Laboratories, Webster, TX) which is designed to measure total hormone concentration; all positive controls were within acceptable ranges. Hormone measurements were performed in duplicate and averaged for a final result.

Statistics. Logistic growth curves were estimated and compared using nonlinear mixed effects regression techniques (SAS Proc NLMIXED) where the final length of the mouse was a random effect. The van Elteren test was used to analyze serum Gh data separately by gender with undetectable values set to the lower limit of the assay at $0.2 \mathrm{ng} / \mathrm{mL}$. To examine the association between Igf-1 and growth, z-scores were assigned to Igf-1, weight, and length values: Z-scores were calculated from the mean and SD for each genotype/ sex/age group separately. Linear regression was then used to regress weight and length Z-scores on Igf-1 z-scores. Differences of mean food intake between WT and CF mice were compared using a $t$ test separately by gender. All other data were analyzed separately by gender using two-way ANOVA with age and genotype as independent variables followed by Bonferroni posttests to compare $\mathrm{CF}$ and WT means within single age groups. A P-value of $<0.05$ was considered significant.

\section{RESULTS}

Growth analysis. CF mice of both genders were consistently smaller than WT mice (Fig. 1A). Mean weight (in grams) \pm SE for mice at time of euthanization was as follows: $31 \mathrm{~d}$ males, $\mathrm{WT}=18.6 \pm 0.7(n=15), \mathrm{CF}=10.3 \pm 0.9$ $(n=10) ; 45 \mathrm{~d}$ males, $\mathrm{WT}=22.2 \pm 0.7(n=13), \mathrm{CF}=14.2$ $\pm 0.8(n=10) ; 84 \mathrm{~d}$ males, WT $=27.2 \pm 0.6(n=14), \mathrm{CF}$ $=18.3 \pm 0.7(n=11) ; 31 \mathrm{~d}$ females, WT $=16.6 \pm 0.4(n=$ $11), \mathrm{CF}=9.5 \pm 0.4(n=12) ; 45 \mathrm{~d}$ females, $\mathrm{WT}=18.5 \pm$ $0.4(n=15), \mathrm{CF}=14.0 \pm 0.6(n=7) ; 84 \mathrm{~d}$ females, $\mathrm{WT}=$ $20.8 \pm 0.4(n=11), \mathrm{CF}=15.4 \pm 0.5(n=7) ; p<0.0001$ for all pairwise comparisons ( $t$ tests). Length measurements indicate that $\mathrm{CF}$ mice of both genders were significantly shorter than WT mice for all ages (Fig. 1B).

$\boldsymbol{I G F}$-1. Insulin like growth factor-1 (Igf-1) is an important regulator of growth in mice (21). There was a significant deficit of serum Igf-1 in both genders of CF mice for all ages ranging from $31-55 \%$ (Fig. $2 A$ ). As most circulating Igf- 1 is derived from the liver $(22,23)$ hepatic Igf- 1 mRNA was measured to determine whether message levels corresponded with depressed serum levels (Fig. 2B). CF males and females both had significantly less hepatic $I g f-1$ mRNA than WT mice at $31 \mathrm{~d}$, but this difference was not significant at $45 \mathrm{~d}$.

To better determine the relationship between serum Igf-1 and growth in our mouse population, we compared serum Igf- 1 with both weight and length using linear regression. To isolate the relationship between serum Igf- 1 and size, the analysis was designed to control for the effects of sex, genotype, and age, which would have confounded the results. Serum Igf-1 positively varied with weight and length in both WT and CF mice (Fig. 3).

Growth hormone. Growth hormone (Gh) positively regulates serum Igf- 1 and also independently stimulates growth (21). There was no significant difference of serum Gh between $\mathrm{CF}$ and WT mice in males (Fig. $4 A ; p=0.90$; van Elteren
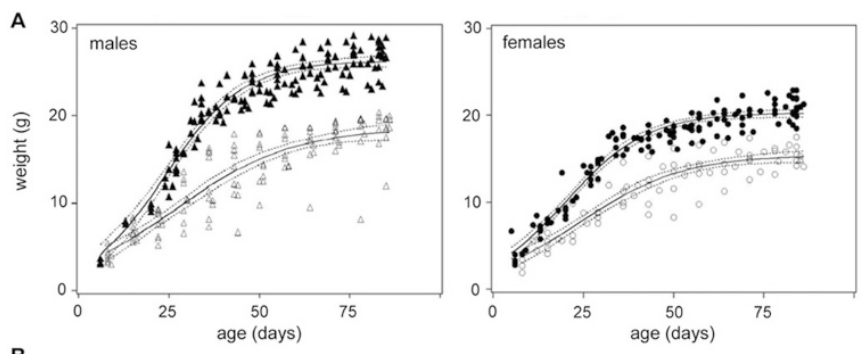

B
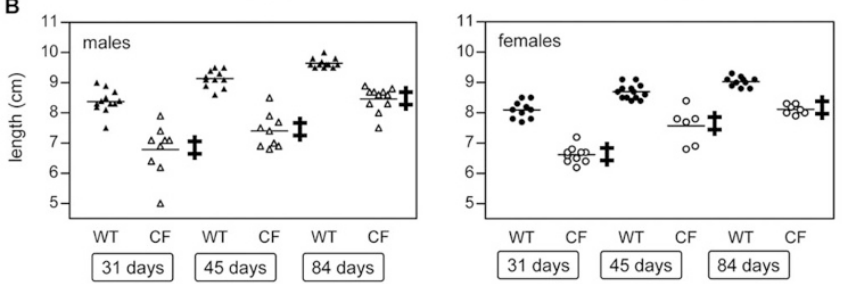

Figure 1. CF mice were smaller as measured by weight $(A)$ and length $(B)$. A: solid curves represent means and dotted curves represent $95 \%$ confidence intervals as calculated using a logistic growth model. $n=81-138 \mathrm{~B}$ : bars represent means. $\ddagger p<0.001$ vs. age-matched WT mice as determined by Bonferroni posttests. $n=6-13$. WT males $(\Delta)$, CF males $(\triangle)$, WT females (O), CF females ( $\mathrm{O})$. 

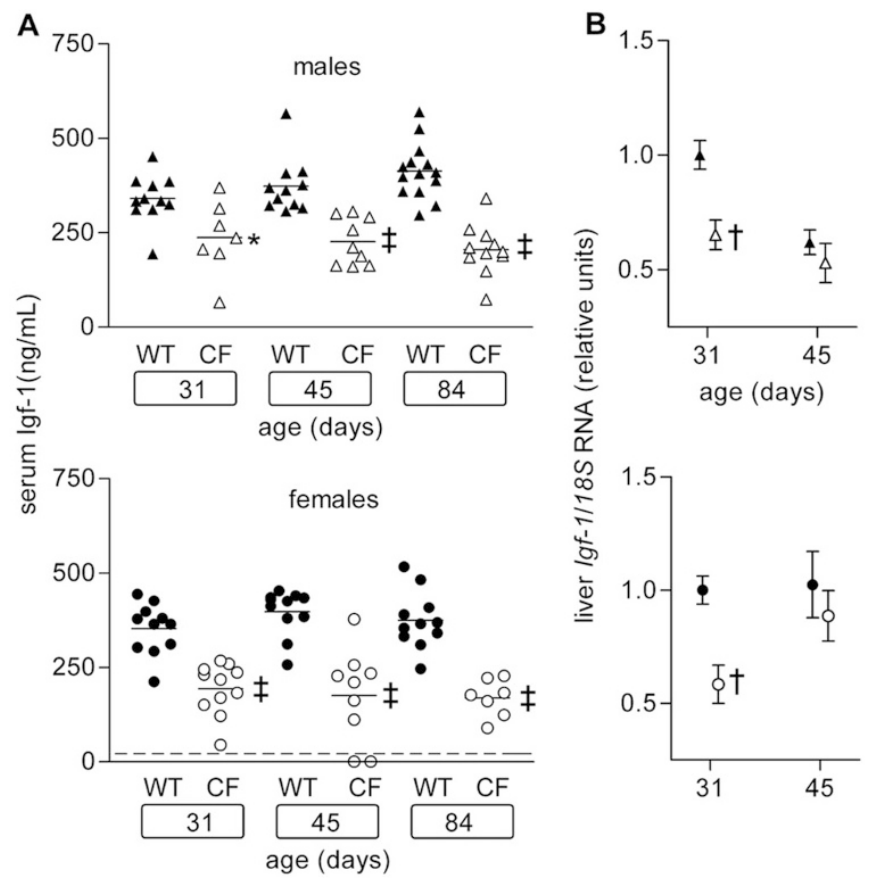

Figure 2. Serum Igf-1 $(A)$ and liver Igf-1 mRNA $(B)$ were reduced in $\mathrm{CF}$ mice. A: Solid lines represent mean values. Undetectable values are below the dotted line and were set at 0 for analysis. B: Values are mean \pm SE and are relative to the $31 \mathrm{~d}$ WT mean which is set at $1(n=9-14$ for $31 \mathrm{~d}$ data; $n=$ 6-10 for $45 \mathrm{~d}$ data except CF females where $n=4)$ ). $* p<0.05, \dagger p<0.01$, and $\ddagger p<0.001 v s$. age-matched WT mice as determined by Bonferroni posttests. WT males $(\boldsymbol{\Delta})$, CF males $(\triangle)$, WT females $(\bullet)$, CF females $(\bigcirc)$.
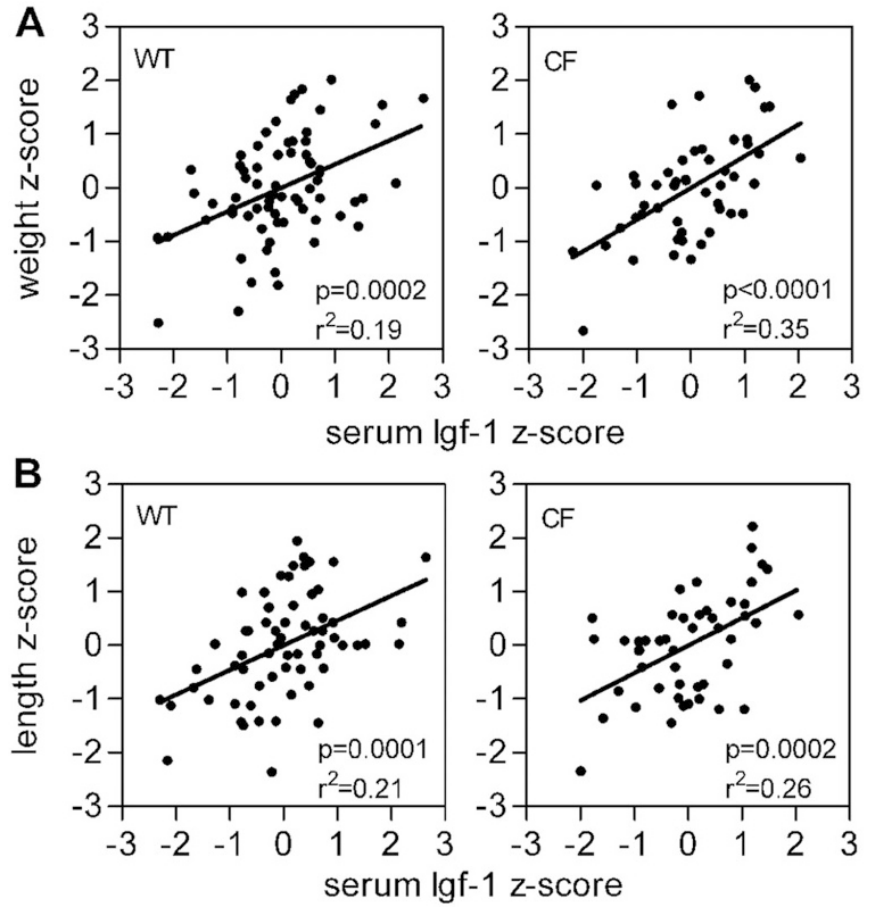

Figure 3. Serum Igf- 1 values correlated with mouse weight $(A)$ and length $(B)$ at time of euthanization as shown using regression analysis of z-scores. WT data are in left panels and CF data are in right panels. Solid lines represent fitted regression lines. P-values and $\mathrm{r}^{2}$ values are as indicated in each figure. Each point represents a single mouse.

test), but there was a nominally significant deficit in $\mathrm{CF}$ females ( $p=0.048$; van Elteren test). Pituitary $G h$ mRNA was also measured (Fig. 4B). In males, CF mice had less $G h$
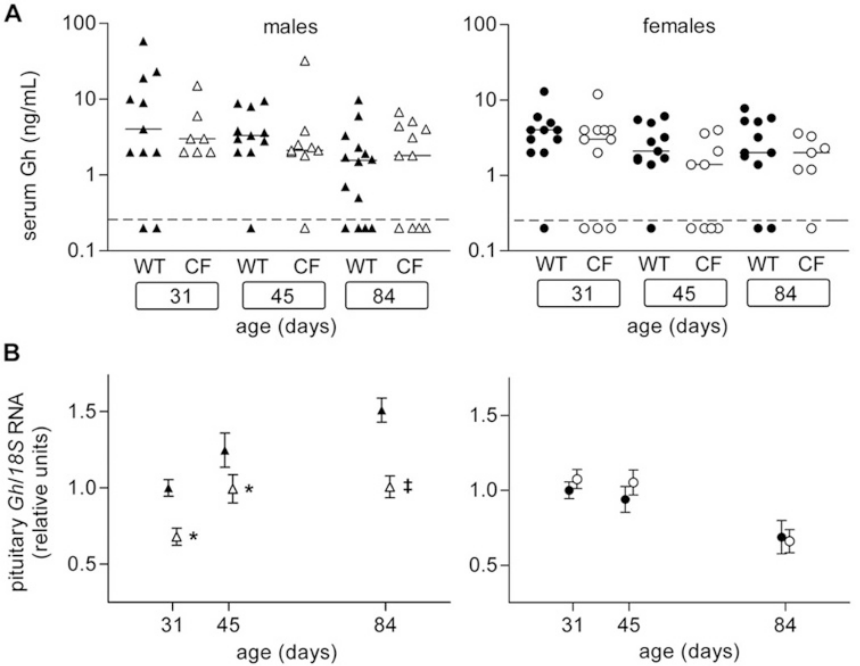

Figure 4. Serum Gh $(A)$ was measured by RIA and pituitary $G h$ mRNA $(B)$ was measured using quantitative PCR. A: Solid lines represent median values and dotted lines represent the detection limit of the assay at $0.2 \mathrm{ng} / \mathrm{mL}$. B: Values are mean $\pm \operatorname{SE}(n=7-11$, except $84 \mathrm{~d}$ CF females where $n=5)$. Values are relative to the $31 \mathrm{~d}$ WT mean which is set at $1 .{ }^{*} p<0.05$, $\ddagger p<$ $0.001 v s$. age-matched WT mice as determined by Bonferroni posttests. WT males $(\boldsymbol{\Delta})$, CF males $(\triangle)$, WT females $(\bullet)$, CF females $(\bigcirc)$.

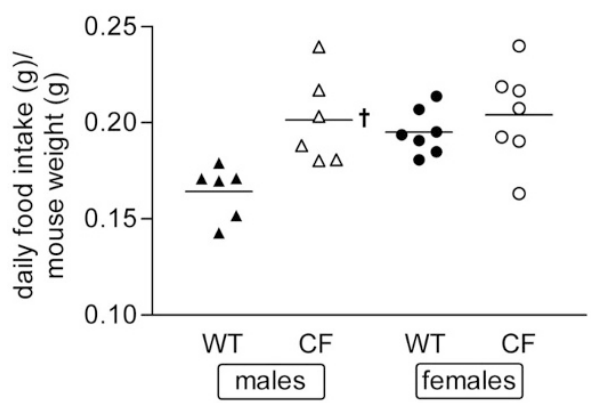

Figure 5. Food intake is reported in units of "daily food intake (g)/mouse weight (g)." Each point represents average food intake for a single mouse over $10 \mathrm{~d}$. Horizontal lines are means. $\dagger p<0.01$ compared with WT mice. WT males $(\boldsymbol{\Delta})$, CF males $(\triangle)$, WT females $(\bullet)$, CF females $(\bigcirc)$.

mRNA at all ages ( $p<0.05$ for day 31 and day 45 mice, $p<$ 0.001 for $84 \mathrm{~d}$ mice; Bonferroni posttests). In females, $G h$ mRNA was not different between CF and WT mice.

Food consumption. The observations of low Igf-1 and reduced growth are consistent with models of malnutrition in rodents (24-26). Since anorexia, or reduced food intake, is one simple explanation for malnutrition, food consumption was measured from age 37 through $46 \mathrm{~d}$. CF males ate more than WT males per unit body weight $(p=0.0074 ; t$ test), whereas CF females ate the same as WT females (Fig. 5). Specifically, food consumption in units of "daily food intake $(\mathrm{g}) /$ mouse weight $(\mathrm{g})$ " $\pm \mathrm{SE}$ was as follows: WT males, $0.164 \pm 0.0057(n=6)$; CF males, $0.202 \pm 0.0096(n=6)$; WT females, $0.195 \pm 0.0044(n=7)$; CF females, $0.204 \pm$ $0.0093(n=7)$.

\section{DISCUSSION}

Growth in CF patients is clinically relevant because it correlates with lung function $(2,3)$. For example, Konstan $e t$ 
al. (2003) showed that growth parameters at age 3 positively predict lung function at age 6 in $\mathrm{CF}$ patients (3). Further evidence that growth stimulation is beneficial to $\mathrm{CF}$ patients is that treatment with $\mathrm{GH}$ not only stimulates growth and elevates serum Igf-1 levels, but may also improve clinical status (5). For example, a randomized, controlled trial found that administration of $\mathrm{GH}$ to $\mathrm{CF}$ patients improves clinical status as measured by lung capacity and reduced hospital visits (4). It is suggested that the beneficial effects of growth hormone may be attributed to increased respiratory muscle strength and larger absolute lung capacity (5).

To assess growth regulation in CF patients, several studies have measured serum concentrations of GH and IGF-1. Several studies have shown significant deficits of Igf-1 in CF patients (27-29). The behavior of $\mathrm{GH}$ in $\mathrm{CF}$ patients is more equivocal, with studies showing higher, normal, or lower levels of the hormone [reviewed in (28)].

Many mouse models of CF have been created which contain various levels of functional Cftr. (30). Several of these strains are smaller than their wild-type counterparts $(14,15)$, including the one used in this study which contains a null mutation in Cftr (15). The absence or reduction of functional Cftr in mice affects several organs. CF mice with null or severe mutations in $\mathrm{Cftr}$ have intestinal disease characterized by mucous accumulation and goblet cell hyperplasia, and a large portion of them die of bowel obstruction before reaching maturity $(17,30)$. Exocrine pancreatic disease in $\mathrm{CF}$ mice is mild compared with humans (who experience fibrosis and complete loss of function) and includes progressive histologic changes without fibrosis $(17,31)$, as well as evidence of decreased functional enzymes (32). CF mice do not have overt lung disease, although they do develop more pronounced disease than healthy mice if inoculated with bacteria (16).

This paper presents a study of growth and major growth regulating hormones in $\mathrm{CF}$ mice. $\mathrm{CF}$ mice were small in mass and linear size (Fig. 1) and also had consistently low levels of serum Igf-1 (Fig. 2A). This is significant in that Igf-1 is the main effector of $\mathrm{Gh}$ and likely accounts for the majority of the growth stimulating effects of Gh (21). Indeed, the present study was consistent with a growth-stimulating role of serum Igf- 1 in that levels of the hormone correlated significantly with the size of mice after controlling for genotype, sex, and age (Fig. 3). Recent evidence has suggested, however, that paracrine-acting Igf-1 from connective tissues such as muscle and bone may be more important for stimulating growth $(22,23)$. It is possible, therefore, that the altered levels of serum Igf-1 in CF mice are reflective of locally produced levels of the hormone, but not directly functionally relevant. The data presented here demonstrate that circulating levels of Igf-1 can serve as a gauge of growth regulation in the context of the CF mouse growth deficiency.

In mice, $\mathrm{Gh}$ is a potent regulator of serum Igf-1 as demonstrated by the fact that mice lacking the $\mathrm{Gh}$ receptor have an $80 \%$ reduction of (33) or undetectable levels of serum Igf-1 (21). We hypothesized that low serum Gh may be responsible for the observed change in Igf-1. There was a marginally significant reduction of serum $\mathrm{Gh}$ in female $\mathrm{CF}$ mice but no difference in males (Fig. 4A). Conversely, male CF mice had reduced pituitary $G h$ mRNA but females did not (Fig. 4B). It is difficult to detect changes in Gh levels by measuring single time points due to the pulsatile nature of the hormone (34). Unfortunately, temporal profiles of Gh designed to detect such changes are impractical in the mouse due to the need for multiple blood samples over a short period of time. Our findings, therefore, may not have adequately resolved differences in pulse amplitude or frequency and thus our measurements may underestimate GH differences. Despite the inherent difficulty in detecting changes in levels of serum Gh, our data show some evidence of Gh down-regulation in both sexes of CF mice.

Our findings in CF mice are consistent with a model of malnutrition causing growth retardation. Various types of induced malnutrition in rodents including starvation and caloric restriction cause reduced serum Gh $(24,25)$ and Igf-1 $(24,26)$. [Note that this differs from the human response to malnutrition which includes elevated $\mathrm{GH}$ and reduced IGF-1 (35)]. This study found that CF mice had low serum Igf-1, as well as evidence of a Gh deficit (although only females had low serum $\mathrm{Gh}$ ). One simple explanation for this finding is that $\mathrm{CF}$ mice consume less food leading to malnutrition and growth retardation. We found, however, that $\mathrm{CF}$ mice ate at least as much as age-matched WT mice (Fig. 5). It is important to note that although $\mathrm{CF}$ mice ate adequately for the studied ages, it is possible that younger $\mathrm{CF}$ mice did not. The ages examined in this study were limited by poor survival in younger, separately caged CF mice. Despite this caveat, the food intake data suggest that $\mathrm{CF}$ mouse growth retardation is caused by consumption-independent mechanisms.

One likely consumption-independent mechanism for growth retardation is malabsorption leading to an energy deficit. CF mice have severe gastrointestinal disease $(16,17)$ and CF mice with a null Cftr mutation have lipid malabsorption (36). We speculate that loss of Cftr function results in intestinal epithelial cell dysfunction, including altered fluid and electrolyte transport, but also malabsorption in this tissue. Malabsorption would be predicted to cause an energy deficit and suppress growth, including reduced production and secretion of Igf-1. To quantify this phenomenon, an important area of future research would be to measure total fecal energy losses in CF mice. Since the CF mouse has minor pancreatic disease $(16,36)$, this experiment would help elucidate the role of primary intestinal disease on malabsorption and growth.

The CF mouse may also be used to study other proposed contributors to the growth defect. First, it has been suggested that hypothalamic Cftr regulates neuropeptide secretion or energy balance regulation, ultimately affecting the growth and reproductive axes $(10,11)$. Study of mice with a neuronspecific deletion of Cftr would help elucidate the role of neuronal Cftr. Second, chronic inflammation may also contribute to growth retardation in CF (7). There is evidence that CF patients have elevated systemic cytokines $(37,38)$ and $\mathrm{CF}$ mice have elevated expression of inflammatory mediators in the intestine (39). Chronic systemic cytokines have been shown to blunt growth and growth hormones (40). To determine whether chronic inflammation is affecting growth in $\mathrm{CF}$ mice, systemic inflammation would have to be demonstrated 
and subsequently manipulated pharmacologically or genetically to elicit a change in growth. Third, several studies have shown that $\mathrm{CF}$ patients have elevated resting energy expenditure which is likely due to increased work of breathing (6). Studies have also suggested, however, that loss of Cftr causes primary cellular energy wasting $(8,9)$. Measurements of energy expenditure in the CF mouse, which has no lung disease but may share a primary energy-wasting defect with humans, would help define the etiology of elevated resting energy expenditure.

In summary, growth has been identified as an important clinical target in cystic fibrosis, but normal growth in CF patients has not been universally achieved. We propose that a mouse model of $\mathrm{CF}$, which is here shown to have severely inhibited growth and low serum Igf-1 despite adequate food intake, will serve to model several potential mechanisms of $\mathrm{CF}$ growth retardation in humans. Specifically, the CF mouse may elucidate the effects on growth of intestinal disease, inflammatory cytokines, hypothalamic Cftr, and a proposed energy wasting defect.

Acknowledgments. We thank Annalisa VanderWyden for contributing technical expertise to several experiments; Dr. Mark Palmert and Dr. Ruth Keri for advice in planning and interpreting experiments and for critical review of this manuscript; and Alma Wilson, Veronica Peck, and Ebony Boyd for expert and compassionate care of our mice.

\section{REFERENCES}

1. Lai HC, Kosorok MR, Sondel SA, Chen ST, FitzSimmons SC, Green CG, Shen G, Walker S, Farrell PM 1998 Growth status in children with cystic fibrosis based on the National Cystic Fibrosis Patient Registry data: evaluation of various criteria used to identify malnutrition. J Pediatr 132:478-485

2. Zemel BS, Jawad AF, FitzSimmons S, Stallings VA 2000 Longitudinal relationship among growth, nutritional status, and pulmonary function in children with cystic fibrosis: analysis of the Cystic Fibrosis Foundation National CF Patient Registry. J Pediatr 137:374-380

3. Konstan MW, Butler SM, Wohl ME, Stoddard M, Matousek R, Wagener JS, Johnson CA, Morgan WJ, Investigators and Coordinators of the Epidemiologic Study of Cystic Fibrosis 2003 Growth and nutritional indexes in early life predict pulmonary function in cystic fibrosis. J Pediatr 142:624-630.

4. Hardin DS, Ellis KJ, Dyson M, Rice J, McConnell R, Seilheimer DK 2001 Growth hormone improves clinical status in prepubertal children with cystic fibrosis: results of a randomized controlled trial. J Pediatr 139:636-642

5. Hardin DS 2004 GH improves growth and clinical status in children with cystic fibrosis - a review of published studies. Eur J Endocrinol 151:S81-S85

6. Pencharz PB, Durie PR 2000 Pathogenesis of malnutrition in cystic fibrosis, and its treatment. Clin Nutr 19:387-394

7. Hankard R, Munck A, Navarro J 2002 Nutrition and growth in cystic fibrosis. Horm Res 58:16-20

8. Shapiro BL 1989 Evidence for a mitochondrial lesion in cystic fibrosis. Life Sci 44:1327-1334

9. Stutts MJ, Knowles MR, Gatzy JT, Boucher RC 1986 Oxygen consumption and ouabain binding sites in cystic fibrosis nasal epithelium. Pediatr Res 20:1316-1320

10. Mulberg AE, Weyler RT, Altschuler SM, Hyde TM 1998 Cystic fibrosis transmembrane conductance regulator expression in human hypothalamus. Neuroreport 9:141-144

11. Weyler RT, Yurko-Mauro KA, Rubenstein R, Kollen WJ, Reenstra W, Altschuler SM, Egan M, Mulberg AE 1999 CFTR is functionally active in GnRH-expressing GT1-7 hypothalamic neurons. Am J Physiol 277:C563-C571

12. Ahme ML, Ong KK, Thomson AH, Dunger DB 2004 Reduced gains in fat and fat-free mass, and elevated leptin levels in children and adolescents with cystic fibrosis. Acta Paediatr 93:1185-1191
13. Stettler N, Kawchak DA, Boyle LL, Propert KJ, Scanlin TF, Stallings VA, Zemel BS 2000 Prospective evaluation of growth, nutritional status, and body composition in children with cystic fibrosis. Am J Clin Nutr 72:407-413

14. Zeiher BG, Eichwald E, Zabner J, Smith JJ, Puga AP, McCray PB Jr., Capecchi MR, Welsh MJ, Thomas KR 1995 A mouse model for the delta F508 allele of cystic fibrosis. J Clin Invest 96:2051-2064

15. Snouwaert JN, Brigman KK, Latour AM, Malouf NN, Boucher RC, Smithies O, Koller BH 1992 An animal model for cystic fibrosis made by gene targeting. Science 257:1083-1088

16. Scholte BJ, Davidson DJ, Wilke M, De Jonge HR 2004 Animal models of cystic fibrosis. J Cyst Fibros 3:183-190

17. Grubb BR, Boucher RC 1999 Pathophysiology of gene-targeted mouse models for cystic fibrosis. Physiol Rev 79:S193-S214

18. Clarke LL, Grubb BR, Gabriel SE, Smithies O, Koller BH, Boucher RC 1992 Defective epithelial chloride transport in a gene-targeted mouse model of cystic fibrosis. Science 257:1125-1128

19. Clarke LL, Gawenis LR, Franklin CL, Harline MC 1996 Increased survival of CFTR knockout mice with an oral osmotic laxative. Lab Anim Sci 46:612-618

20. Pfaffl MW 2001 A new mathematical model for relative quantification in real-time RT-PCR. Nucleic Acids Res 29:e45-

21. Lupu F, Terwilliger JD, Lee K, Segre GV, Efstratiadis A 2001 Roles of growth hormone and insulin-like growth factor 1 in mouse postnatal growth. Dev Biol 229:141-162

22. Yakar S, Liu JL, Stannard B, Butler A, Accili D, Sauer B, LeRoith D 1999 Normal growth and development in the absence of hepatic insulin-like growth factor I. Proc Natl Acad Sci U S A 96:7324-7329

23. Sjogren K, Liu JL, Blad K, Skrtic S, Vidal O, Wallenius V, LeRoith D, Tornell J, Isaksson OG, Jansson JO, Ohlsson C 1999 Liver-derived insulin-like growth factor I (IGF-I) is the principal source of IGF-I in blood but is not required for postnatal body growth in mice. Proc Natl Acad Sci U S A 96:7088-7092

24. Park S, Sohn S, Kineman RD 2004 Fasting-induced changes in the hypothalamicpituitary-GH axis in the absence of GH expression: lessons from the spontaneous dwarf rat. J Endocrinol 180:369-378

25. Ortiz-Caro J, Gonzalez C, Jolin T 1984 Diurnal variations of plasma growth hormone, thyrotropin, thyroxine, and triiodothyronine in streptozotocin-diabetic and food-restricted rats. Endocrinology 115:2227-2232

26. Sohlstrom A, Katsman A, Kind KL, Grant PA, Owens PC, Robinson JS, Owens JA 1998 Effects of acute and chronic food restriction on the insulin-like growth factor axis in the guinea pig. J Endocrinol 157:107-114

27. Laursen EM, Juul A, Lanng S, Hoiby N, Koch C, Muller J, Skakkebaek NE 1995 Diminished concentrations of insulin-like growth factor I in cystic fibrosis. Arch Dis Child 72:494-497

28. Laursen EM, Lanng S, Rasmussen MH, Koch C, Skakkebaek NE, Muller J 1999 Normal spontaneous and stimulated GH levels despite decreased IGF-I concentrations in cystic fibrosis patients. Eur J Endocrinol 140:315-321

29. Taylor AM, Bush A, Thomson A, Oades PJ, Marchant JL, Bruce-Morgan C, Holly J, Ahmed L, Dunger DB 1997 Relation between insulin-like growth factor-I, body mass index, and clinical status in cystic fibrosis. Arch Dis Child 76:304-309

30. Davidson DJ, Rolfe M 2001 Mouse models of cystic fibrosis. Trends Genet 17:S29-S37

31. Durie PR, Kent G, Phillips MJ, Ackerley CA 2004 Characteristic multiorgan pathology of cystic fibrosis in a long-living cystic fibrosis transmembrane regulator knockout murine model. Am J Pathol 164:1481-1493

32. Ip WF, Bronsveld I, Kent G, Corey M, Durie PR 1996 Exocrine pancreatic alterations in long-lived surviving cystic fibrosis mice. Pediatr Res 40:242-249

33. Coschigano KT, Holland AN, Riders ME, List EO, Flyvbjerg A, Kopchick JJ 2003 Deletion, but not antagonism, of the mouse growth hormone receptor results in severely decreased body weights, insulin, and insulin-like growth factor I levels and increased life span. Endocrinology 144:3799-3810

34. Butler AA, Le Roith D 2001 Control of growth by the somatropic axis: growth hormone and the insulin-like growth factors have related and independent roles. Annu Rev Physiol 63:141-164

35. Scacchi M, Ida Pincelli A, Cavagnini F 2003 Nutritional status in the neuroendocrine control of growth hormone secretion: the model of anorexia nervosa. Front Neuroendocrinol 24:200-224

36. Bijvelds MJ, Bronsveld I, Havinga R, Sinaasappel M, de Jonge HR, Verkade HJ 2005 Fat absorption in cystic fibrosis mice is impeded by defective lipolysis and post-lipolytic events. Am J Physiol Gastrointest Liver Physiol 288:G646-G653

37. Levy E, Gurbindo C, Lacaille F, Paradis K, Thibault L, Seidman E 1993 Circulating tumor necrosis factor-alpha levels and lipid abnormalities in patients with cystic fibrosis. Pediatr Res 34:162-166

38. Nixon LS, Yung B, Bell SC, Elborn JS, Shale DJ 1998 Circulating immunoreactive interleukin-6 in cystic fibrosis. Am J Respir Crit Care Med 157:1764-1769

39. Norkina O, Kaur S, Ziemer D, De Lisle RC 2004 Inflammation of the cystic fibrosis mouse small intestine. Am J Physiol Gastrointest Liver Physiol 286:G1032-G1041

40. De Benedetti F, Alonzi T, Moretta A, Lazzaro D, Costa P, Poli V, Martini A, Ciliberto G, Fattori E 1997 Interleukin 6 causes growth impairment in transgenic mice through a decrease in insulin-like growth factor-I. A model for stunted growth in children with chronic inflammation. J Clin Invest 99:643-650 